\title{
The Branded Hotel as an Element of Destination Branding
}

\author{
Elizabeth Abiola-Oke \\ Department of Transport and Tourism Studies, Redeemer's University, Nigeria \\ jacobe@run.edu.ng
}

The purpose of this article was to examine the effect of the availability of hotel brands in a destination on the promotion of the destination. Data for this study were collected through online questionnaires from a diverse population. The respondents were reached via a social medium (LinkedIn, on which the author has an account) and membership in different tourism-related and non-tourism related groups. The tourism-related groups are made up of both professionals in the field and nonprofessionals. The data were analysed using descriptive analysis (tables, cross tabulation, and Spearman ranked correlation) with spss. It was discovered that hotel brands have little impact on the choice of destination to visit in comparison to other elements of a destination, such as attraction, transportation, and other supporting services. Therefore, a hotel brand cannot be used as the sole element of destination branding as it has little or no effect on branding a destination.

Keywords: hotel branding, destination branding, destination marketing, destination promotion

https://doi.org/10.26493/2335-4194.12.83-96

\section{Introduction}

Accommodation in the forms of hotels, hostels, and other types are essential parts of a destination, and they create the feeling of welcome and a lasting impression on the tourists when they visit (Cooper, 2012). Anyone travelling to visit a destination away from their usual place of residence for any purpose requires accommodation. While some might have friends and family at the destination, some may not, but they both need a place to stay, especially when staying for more than a day. This contributes to the experience of the tourists at the destination, which is paramount for the promotion of the destination (Cooper, 2012). In addition, according to Ismail (2011), factors such as brand name, price, advertising, word of mouth, and experience determine the type of experience a customer would have on a product or services and also determines their loyalty. Hence, the importance of accommodation facilities at the destination.
Regarding how the brand of hotel in a destination determines the choice of a gaming destination, Dioko and So (2012) determined that the brand of hotel does not determine the choice of destination; they recommended a further study on the topic. Their study was limited to one destination (Macao); therefore, they said that a conclusive statement could be made on the topic and that to make a generalised statement, visitors to other destinations have to be surveyed. While accommodation providers are not the only service providers that make up the destination brand, from the perspective of the researcher, they are the major service provider without which destinations cannot be complete. According to Pike (2005); Morgan, Pritchard, and Piggott (2003), and Pritchard and Morgan (2001), destination branding is complex, as there are still many destinations yet to be studied in applying branding to the marketing principles of destinations (Dioko \& So, 2012). 
The following are the objectives of the research:

1. To know if the brands of hotels in the destination influence the choice of destination.

2. To examine the influence of hotel brand information on the promotion of tourism destinations.

\section{Research Hypotheses}

1. Accommodation facilities, in terms of their brand as a key element of a destination, have no effect on the inspiration for a choice of destination.

2. There is no significant relationship between loyalty to a hotel brand with the inspiration for the choice of a destination.

\section{Hotel Branding}

According to Medlik and Ingram (2000), hotels play essential roles in most countries by providing facilities for business transactions, for meetings and conferences, and for recreation and entertainment. As identified by Medlik and Ingram (200o), the hotel is both for accommodation and for the transaction of business. This is the aspect of the use of space, especially the lobbies and the lounges for purposes of meetings and business transactions. The hotel business as a service business operates to provide accommodation and other needs of the people during their stay (Bhatia, 2006). The mode of operation and revenue generation can be analysed from the way the business is structured, i.e., its organisational structure. The structure of any hotel would be based on its size, such as luxury hotel, economy/budget hotel, boutique hotels, lifestyle hotel (Freund de Klumbis, 2002); all of these also enhance the branding of a hotel based on the type of service it promises to deliver.

This is because the hospitality industry has grown over the years from the traditional hospitality service to a more comprehensive service - diverse in its operation (Berger \& Chiafor Jr., 2007). The industry includes accommodation, catering, and places for socialising (Nailon, 1982). Due to the change in the needs of people and for the enhancement of competition among operators, there is a need for the uniqueness of the organisations in the industry, and this is the essence of branding and other distinguishing concepts of marketing (Forsgren \& Franchetti, 2004). Branding is one of the concepts of differentiation (Dioko \& So, 2012) used by marketers in the industry.

Hotels have always been identified by their names, which shows that they held the common features of a product brand - the name (Connell, 1992). According to Olsen, Chung, Graf, Lee, and Madanoglu (2004), to capitalise on brand identification and differentiation in the face of competition, and to facilitate growth strategies, marketing executives have employed brand value, brand premium, brand equity, brand awareness, and brand image to enhance competition, from the aspect of management contracts and approaches to meet corporate goals. This affirms that branding is far more than merely having a name.

\section{Destination Branding}

Branding as a marketing concept also applies to destinations (Hankinson, 2005) because the products of tourism are also homogenous and there is a need for the identification of a unique factor for differentiation. Branding has gone beyond merely having a logo, sign, symbol, term, design, or combination of these (Blain, 2001). It has to do with the delivery of service to complement the name of the organisation and what they have to offer. According to Veríssimo, Tiago, Tiago, and Jardim (2017), destination branding is becoming a powerful marketing; this further emphasises the need for brand management.

\section{Brand Management}

Brand management is used in the construction of brand meaning, value, quality, personality and identity (Iglesias \& Bonet, 2012). According to Jevons, Gabbot, and De Chernatony (2005), brand meaning is influenced by the high level of influences, of which some can be controlled and some cannot but can be viewed and observed. It is essential, therefore, that the owners of brands ensure that high-quality service aligned with vision is delivered with a genuine commitment to the satisfaction of their customers (Blackett, 2004).

\section{Brand Identity}

Brand identity is the tangible aspect of the brand that can be seen and felt, ensures recognition, allows for 
differentiation, and makes the brand accessible (Alina, 2009). Brand identity, according to Kapferer (2008), is the internal construct of the product based on the view of the organisation in terms of what they want the brand to be. This requires stability and consistency to ensure that the brand is what it is intended for it to be (Da Silveira, Lages, \& Simoes, 2013). Brand identity can help the organisation in navigating and adapting to market changes (Da Silveira et al., 2013). In the opinion of Da Silveira et al. (2013), brand identity is not merely created by the organisation alone: it is essential to understand that the consumers also create the identity of the brand and this helps in the creation of value.

Just as the brand is an asset to the organisation, so too is the brand an investment for the consumers, and there has to be value gained that would be worth the investment made. Therefore, the argument of Kapferer (2008), asserting that brand identity emanates from the organisation and requires stability, can be said to be insufficient to explain brand identity as we are now in a global world with a dynamic environment. Consequently, for the survival of any brand, the identity should be made to suit the environmental condition as it changes. When the perspective of the consumers is viewed in the creation of an identity for the brand and the dynamism of the environment is also considered, the creation of brand identity will not be just from the internal perspective alone, and this would create a proper identity for the brand that will suit both the organisation and the consumers.

\section{Brand Value}

According to Aaker (1991), brand value is the awareness of the brand, its quality perception and the overall satisfaction the customers derives from making use of the brand. Chu and Keh (2006) pointed out that brand value is significant at two levels: the micro (consumer) and macro (firm) levels, each with different effects. On the consumer level, it positively affects the behavioural outcomes, including the intention to purchase (CobbWalgren, Ruble, \& Donthu, 1995), while at the firm level, it affects the perception of investors and the financial analysts, which subsequently determines the stock prices (Simon \& Sullivan, 1993).

\section{Brand Experience}

Brand experience is the feel of the brand that the consumers have when they make use of the brand. This is an essential part of brand management, and it can lead to brand loyalty, depending on whether the experience is positive or negative (Iglesias, Singh, \& Batista-Foguet, 2011). Brand experience is the impression taken away by the consumer (Carbone \& Haeckel, 1994) as a result of making use of the brand or having an encounter with it (Klaus \& Maklan, 2007). Good customer experience is essential to any business, and having a brand requires more from the brand owner. This is because it is assumed that any branded product is a promise of quality, and anything short of this is questionable.

\section{Brand Equity}

Brand plays a vital role in the promotion of a business, company or organisation, and to the customers as well. This is highlighted by Keller and Lehmann (2006) to being composed of three primary roles: the customer market, the product market, and the financial market. In the case of the consumer market, brands make it easy for the identification of products by the simplification of choice, the promise of quality to a particular level, and the reduction of risk and/or engendering trust. It plays a marketing role by ensuring effective marketing efforts; for the financial role, brands are assets (intangible) in a financial sense (Keller \& Lehmann, 2006). All value of these roles are the brand equity (Aaker, 1991). In the words of Randall (2000), brand equity is the value of the brand to both the consumers and the organisation that owns the brand. According to Morgan et al. (2003), the makeup (DNA) of a destination is expected to reflect the value of the brand and its unique propositions in the eyes of the customer.

\section{Brand Image}

The brand management components discussed above constitute an image for a brand; it us vital for any business to manage its brand appropriately. The prior perception of a brand image is created by the proper management of the brand, but the image created for the brand after the consumers' use of the brand is equally significant. This is because it is seen as an essential 
tool with the ability to influence the perception of the customer of a good or service offered, thereby having an impact on customer behaviour (Zeithaml \& Bitner, 1996).

Furthermore, image also influences the loyalty of customers to an organisation, their enthusiasm, and satisfaction depending on the type of image created in the minds of the customers (Kandampully \& Suhartanto, 2000; Binkowska, 2005). Branding is used to gain the loyalty of customers, but the image created in the mind of the people as regards the brand can either ensure loyalty or not; this is where brand management becomes important, as emphasised earlier. This is because branding is a form of promise made by the organisation to provide the service or products at a certain standard, distinct from others (Kotler \& Gertner, 2004). The concept of brand image is the examination of the overall information held by a consumer of a product/service brand including the brand quality and value (Ashton \& Scott, 2011). Branding, however, allows for differentiation in the marketplace and the creation of the image of the organisation in the mind of the people by creating value (Johnson \& Scholes, 2001).

According to Aaker (1991; 1996) and Keller (1998), the achievement of successful brand management is dependent on the enhancement of brand value or equity. Brand equity, according to Aaker (1991), is the value of a brand as a valuable company asset, to the consumer and the company. The value of a brand to the consumer is identified in the image created of such a brand in the mind of a consumer. According to Qu, Kim, and Im (2011), the image of a product/destination/service mediates between the brand associations, cognitive, affective, and unique image components and the future behaviour of buyers.

\section{Destination Marketing}

Pike (2008) defined a destination as a geographical space accommodating the existence of a cluster of tourism resources and being less of a political boundary. Furthermore, on the definition of a destination, Leiper (1995) defined a tourist destination as a place where people choose to visit for the purpose of having an experience of certain features of the destination, and Buhalis (2000) said it can also be viewed as a perpetual concept which can be interpreted by the tourists subjectively based on their experience, purpose of visit, cultural background, and psychographic and demographic characteristics (Periera, Correia, \& Schutz, 2012). Destinations are representations of the tourism industry as they are the place where the tourism activities occur and where the service providers of the industry are located to meet the needs of the tourists.

Marketing a destination, also known as place marketing, is a distinct task (Ashworth, 1993) and requires more complex managerial activities than the product does in its branding (Karavatsis \& Ashworth, 2005). Of all the products of tourism, the destination is one of the most difficult to manage and market (Fyall \& Leask, 2006) yet also the most important (Cooper, 2012). Destination marketing, according to Elbe, Hallen, and Axelsson (2009) is the deliberate strategically developed activities carried out in order to attract visitors to a destination. Due to the complexity of the nature of the destination, its marketing, as suggested by Helfert, Ritter, and Walter (2002), should be a relational approach. Even with the complexity of marketing destinations, Fyall and Garrod (2005) suggests that for destination marketing to be successful, it is necessary that the customers be engaged in the marketing activities and provide information about the experience they demand.

In line with the above, Dioko and So (2012) are of the opinion that for a relatively unknown destination, the entrance of international branded hotels enhances its marketing and the image of the places where new concepts of leisure and entertainments are introduced, and these are integrated with the core of accommodation services. This is also applicable to established and well-branded destinations. Furthermore, their findings confirmed this in the case of the Macao gaming centre. However, this can be seen as limited as as it was only tested on one particular gaming destination.

According to Cooper (2012), to effectively market a destination, branding of the destination is expedient for unique identification and differentiation among other destinations. This is also supported by Morgan, Pritchard, and Pride (2004), who consider destination branding to bea potent marketing tool, in con- 
trast to some researchers who find destination branding to be a complex concept. Therefore, Cai (2002) defined destination branding as a selection of consistent element mix of a destination used to identify and distinguish the destination among other destinations, while Gilmore (2002) sees destination branding as a re-positioning concept, and Curtis (2001) sees destination branding as the reconstruction of the destination (Park \& Petric, 2006).

The complexity of destination branding due to the nature of the destination and what is involved requires proper management: hence, the role of Destination Marketing Organisations (DMOs) as solely responsible for the marketing of the destination (Elbe et al., 2009). Part of the responsibilities of the DMO in promoting the destination is the branding of the destination. Although the destination is made up of individual service providers and other stakeholders, the Dmos are responsible for the promotion of the destination to tourists, known as destination marketing.

\section{Destination Promotion}

The survival of any business is dependent on meeting the needs of the people/customers as the needs and desires of the people are changing now due to their changing lifestyles and other environmental factors (Shoemaker \& Shaw, 2008). Branding is believed to help create an image in the minds of the guest, and that helps in the promotion of a hotel. It has also been proven by research that branding adds value to hotels than the usual contributors (O’Neill \& Xiao, 2006). The choice of a destination according to Kotler and Gertner (2004) begins with the collection of information before visiting the place and the ability to make sense of the information collected on the destination. Information about accommodation facilities available at the destination is one type of information that a tourist would seek before deciding, which can create an image of the destination in the mind of the tourist. Due to internationalisation, hotels of different brands can be found in different locations/destinations, which often attracts or has the potential to attract visitors. This, therefore, indicates the possibility of the two industries complementing each other.

In promoting tourism destinations, the various tourism enterprises have a role to play in creating an image of the destination. Aside from this fact on the promotion of a destination, customer experience is of utmost importance. No tourism enterprise can be without patronage from tourists and, for there to be patronage, the environment in which the organisation is located is of utmost importance. DMOs are charged with the responsibility of making a difference in the context of the growth of destination choices (Wahab \& Cooper, 2001; Stamboulis \& Skayannis, 2003; Pike, 2004).

\section{Research Methodology}

In carrying out this study, a survey research design was utilised. According to (MacDonald \& Headlam, n.d.), the survey research method is commonly used in collecting primary data, involves measurement procedures involving asking respondents questions, and they are flexible tools used in gathering both qualitative and quantitative data. Therefore, for this research, both quantitative and qualitative data was collected, thereby reflecting mixed method research. According to Creswell (2003), the mixed method is the process of the collection of both qualitative and quantitative data. It can also be seen as the combination of both numeric and narrative data in research (Aaron, 2011).

In collecting both the quantitative and qualitative data, as recommended by Bhattacherjee (2012), a combination of techniques is required, such as questionnaires, interviews, observation etc; alternatively, in the case of highly structured survey questionnaires, both qualitative and quantitative data can only be achieved by designing the questionnaire by using both closed-ended and open-ended questions. This has been adopted in carrying out this study. Therefore, the subjects of this are diverse and have in one time or the other visited different destinations. Because the questionnaire was uploaded online, there is no specified sample frame for the research, and the sample frame for an online questionnaire survey is based on convenience (Veal, 2011).

An online questionnaire was designed to collect both quantitative and qualitative data for the study, using Google Forms; the link to it was sent to respondents via LinkedIn, Facebook, and Twitter. As indi- 
cated earlier, Dioko and So (2012) carried out similar research on a destination. Hence, this study approached it from the perspective of obtaining respondents from diverse countries who had visited different destinations. Twenty-three questions were asked in the questionnaire using multiple choice questions and ranking questions for the closed-ended questions, and providing an avenue for the people to explain the choice of their answer to some of the closed-ended questions using the open-ended questions (Matthews \& Ross, 2010).

The questionnaire was divided into four sections. The first segment asked questions on the demographic characteristics of the respondent. This is to enable the researcher to develop an idea of the respondent, especially regarding their occupation and economic status. The second segment asked questions about the travel experience of the respondents to determine how often they travel and their opinions on the destinations they have visited. The third segment was based on the tourism destination features that influence the decisions of the respondents in their choice during their search on the destination to visit. This is in line with the opinion of Gartner (1993), who says that the image of a destination from the perspective of the tourists is influenced by the information they have on the destination.

In this segment of the questionnaire, five questions were asked; three of the five questions were ranking questions. Options were given, and the respondents were asked to rank them according to their opinion. The fourth segment asked questions on the hotel and destination choice of the respondents. In this segment, a question on the influence of hotel branding on the choice of destination was asked, regarding what would happen if the hotel brand to which they are loyal were unable to provide them with accommodation for them due to being fully booked. Options were provided for them to choose the action they would take.

\section{Analysis}

The data collected, both quantitative and qualitative, were analysed in the same manner. The data were analysed using both descriptive and inferential analysis with the aid of the Statistical Package for So- cial Sciences (SPSS). Descriptive analysis was used in analysing the frequency of responses and the profile of respondents. The inferential analysis was carried out using the Pearson Correlation co-efficient. According to Asuero, Sayago, and González (2006), the correlation coefficient is the measure of the degree of association between two variables. For this study, the Pearson Product-moment correlation was used to test for a linear relationship.

\section{Findings}

A total of 99 responses were collated due to the time constraints. The responses were analysed, and the following are the results of the findings.

\section{Descriptive Analysis}

A total of 99 respondents responded to the online questionnaire. Table 1 gives an overview of the demography of the respondents. Of the 99 respondents to the questionnaire, 39 were male, and 60 were females. The age of the respondents also varies, cutting across almost all age groups: $18-25$ years constituted $33.3 \%, 26-33$ years made up 33.3\%, 34-41 years constituted $13.1 \%$, 42-49 years made up 5.1\%, 50-57 years made up $6.1 \%$, while above 57 years were $9.1 \%$ of the respondents.

Regarding marital status, $55.6 \%$ of the respondents are singles, while $34.3 \%$ are married. The remaining are divorced, widowed and in relationships, constituting a total of $9 \%$, but one of the respondents did not fill in their marital status. Regarding the economic status of the respondents, the majority were in full-time paid work (40.4\%, 13.1\% worked part-time, 30.3\% are students (in full-time education), and the remaining are retired, unemployed and entrepreneurs making up a total of $16.2 \%$.

As stated in the methodology section, the research was targeted towards a diverse population from different countries around the world who have also visited different places around the world. Hence, Table 2 shows the diversity in the nationality of the participant, spanning almost all countries in the world. These people were contacted through the use of social media. 
Table 1 Respondents' Demography (\%)

\begin{tabular}{|c|c|c|}
\hline \multirow{2}{*}{$\begin{array}{l}\text { Travel in the last } \\
12 \text { months }\end{array}$} & Yes & 93 \\
\hline & No & 6 \\
\hline \multirow[t]{2}{*}{ Gender } & Male & 39 \\
\hline & Female & 60 \\
\hline \multirow[t]{6}{*}{ Age Range } & $18-25$ & 33 \\
\hline & $26-33$ & 33 \\
\hline & $34-41$ & 13 \\
\hline & $42-49$ & 5 \\
\hline & $50-57$ & 6 \\
\hline & 58 and above & 9 \\
\hline \multirow[t]{6}{*}{ Marital Status } & Single & 55 \\
\hline & Married & 34 \\
\hline & Divorced & 4 \\
\hline & Widow/widower & 2 \\
\hline & Other & 3 \\
\hline & Missing value & 1 \\
\hline \multirow[t]{6}{*}{ Economic Status } & In full-time paid work & 40 \\
\hline & In part-time paid work & 13 \\
\hline & In full-the education & 30 \\
\hline & Retired & 2 \\
\hline & Unemployed & 7 \\
\hline & Others - entrepreneur & 7 \\
\hline \multirow[t]{5}{*}{ Nationality } & African & 13 \\
\hline & Asians & 36 \\
\hline & Europeans & 41 \\
\hline & Americans & 8 \\
\hline & Australians & 1 \\
\hline \multirow{3}{*}{$\begin{array}{l}\text { No. of travel times } \\
\text { within } 12 \text { months }\end{array}$} & $1-4$ times & 80 \\
\hline & 5-8 times & 13 \\
\hline & Above 8 times & 6 \\
\hline
\end{tabular}

To identify the type of accommodation the respondents make use of when they visit a destination, a question was asked on this and the responses indicated that $58.6 \%$ of the respondents make use of hotels, $14.1 \%$ makes use of hostels, $14.1 \%$ stays with family and friends, while $13.1 \%$ makes use of guest houses at the destination, as shown in Table 3. Following identification of the most used type of accommodation,
Table 2 Nationality of Participants

\begin{tabular}{|c|c|c|c|c|}
\hline Nationality & (1) & (2) & (3) & (4) \\
\hline Middle East & 1 & 1.0 & 1.0 & 1.0 \\
\hline American & 2 & 2.0 & 2.0 & 3.0 \\
\hline Australian (perm. resident) & 1 & 1.0 & 1.0 & 4.0 \\
\hline Brazilian & 1 & 1.0 & 1.0 & 5.1 \\
\hline British & 16 & 16.2 & 16.2 & 21.2 \\
\hline Cameroonian & 1 & 1.0 & 1.0 & 22.2 \\
\hline Canadian & 5 & 5.1 & 5.1 & $27 \cdot 3$ \\
\hline Chinese & 7 & 7.1 & 7.1 & $34 \cdot 3$ \\
\hline Croatian & 1 & 1.0 & 1.0 & 35.4 \\
\hline Danish & 1 & 1.0 & 1.0 & 36.4 \\
\hline Dominican & 1 & 1.0 & 1.0 & $37 \cdot 4$ \\
\hline Dutch & 4 & 4.0 & 4.0 & 41.4 \\
\hline Egyptian & 1 & 1.0 & 1.0 & 42.4 \\
\hline Finnish & 1 & 1.0 & 1.0 & 43.4 \\
\hline French & 2 & 2.0 & 2.0 & 45.5 \\
\hline German & 3 & 3.0 & 3.0 & 48.5 \\
\hline Ghanaian & 1 & 1.0 & 1.0 & 49.5 \\
\hline Greek & 4 & 4.0 & 4.0 & $53 \cdot 5$ \\
\hline Indian & 3 & 3.0 & 3.0 & 56.6 \\
\hline Indonesian & 1 & 1.0 & 1.0 & 57.6 \\
\hline Iranian & 11 & 11.1 & 11.1 & 68.7 \\
\hline Italian & 3 & 3.0 & 3.0 & 71.7 \\
\hline Jamaican & 1 & 1.0 & 1.0 & 72.7 \\
\hline Latvian & 1 & 1.0 & 1.0 & 73.7 \\
\hline Malaysian & 12 & 12.1 & 12.1 & 85.9 \\
\hline Nigerian & 7 & 7.1 & 7.1 & 92.9 \\
\hline Polish & 1 & 1.0 & 1.0 & 93.9 \\
\hline Portuguese & 1 & 1.0 & 1.0 & 94.9 \\
\hline Serbian & 1 & 1.0 & 1.0 & 96.0 \\
\hline South African & 1 & 1.0 & 1.0 & 97.0 \\
\hline Spanish & 1 & 1.0 & 1.0 & 98.0 \\
\hline Ugandan & 2 & 2.0 & 2.0 & 100.0 \\
\hline Total & 99 & 100.0 & 100.0 & \\
\hline
\end{tabular}

Notes Column headings are as follows: (1) frequency, (2) percent, (3) valid percent, (4) cumulative percent.

a question was asked regarding the decision the respondents would make should their choice of ho- 
Table 3 Types of Accommodation Frequently Used

\begin{tabular}{|c|c|c|c|c|}
\hline Type of accommodation & (1) & (2) & (3) & (4) \\
\hline Hostel & 14 & 14.1 & 14.1 & 14.1 \\
\hline Guest house & 13 & 13.1 & 13.1 & $27 \cdot 3$ \\
\hline Hotels & 58 & 58.6 & 58.6 & 85.9 \\
\hline Stay with family and friends & 14 & 14.1 & 14.1 & 100.0 \\
\hline Total & 99 & 100.0 & 100.0 & \\
\hline \multicolumn{5}{|c|}{$\begin{array}{l}\text { Notes Column headings are as follows: (1) } \\
\text { percent, (3) valid percent, (4) cumulative perc } \\
\text { Table } 4 \text { Non-Availability of Preferred Hotel }\end{array}$} \\
\hline Solution & (1) & (2) & (3) & (4) \\
\hline $\begin{array}{l}\text { Look for another accommo- } \\
\text { dation within the destina- } \\
\text { tion }\end{array}$ & 83 & 83.8 & 83.8 & 83.8 \\
\hline $\begin{array}{l}\text { Postpone the trip till when I } \\
\text { can book for the accommo- } \\
\text { dation at the destination }\end{array}$ & 8 & 8.1 & 8.1 & 91.9 \\
\hline $\begin{array}{l}\text { Cancel the trip and search } \\
\text { for another destination with } \\
\text { the same hotel brand }\end{array}$ & 3 & 3.0 & 3.0 & 94.9 \\
\hline $\begin{array}{l}\text { Cancel the trip and look for } \\
\text { another destination }\end{array}$ & 5 & 5.1 & 5.1 & 100.0 \\
\hline Total & 99 & 100.0 & 100.0 & \\
\hline
\end{tabular}

Notes Column headings are as follows: (1) frequency, (2) percent, (3) valid percent, (4) cumulative percent.

tel/accommodation not be available for the date they intend to visit the destination: $83.8 \%$ indicated they would look for other accommodation within the destination, $8.1 \%$ said they would postpone the trip until they could get their preferred hotel, 3.0\% indicated they would cancel the trip and search for another destination with the same brand of hotel, while $5.1 \%$ indicated they would cancel the trip and look for another destination. This, therefore, shows that a total of $16.2 \%$ of the respondents are more loyal to the hotel brand. This is shown in Table 4.

Following the above question on a decision about the preferred hotel, a question on what inspires the choice of a destination was expedient was asked; $71.7 \%$ of respondants indicated that the attractions at the destination inspire them the most, $14.1 \%$ indicated that
Table 5 Inspiration for Choice of Destination

\begin{tabular}{|c|c|c|c|c|c|}
\hline \multicolumn{2}{|l|}{ Nationality } & (1) & (2) & (3) & (4) \\
\hline \multicolumn{2}{|c|}{ Attractions at the destination } & 71 & 71.7 & 71.7 & 71.7 \\
\hline \multicolumn{2}{|l|}{ Accessibility } & 14 & 14.1 & 14.1 & 85.9 \\
\hline \multicolumn{2}{|l|}{ Accommodation } & 6 & 6.1 & 6.1 & 91.9 \\
\hline \multicolumn{2}{|l|}{ Others } & 8 & 8.1 & 8.1 & 100.0 \\
\hline \multicolumn{2}{|l|}{ Total } & 99 & 100.0 & 100.0 & \\
\hline \multicolumn{6}{|c|}{$\begin{array}{l}\text { Notes Column headings are as follows: (1) frequency, (2) } \\
\text { percent, (3) valid percent, (4) cumulative percent. }\end{array}$} \\
\hline \multicolumn{6}{|c|}{$\begin{array}{l}\text { Table } 6 \text { Choice of Destination Inspiration } \\
\text { and Non-Availability of Preferred Hotel }\end{array}$} \\
\hline \multirow[t]{2}{*}{$\begin{array}{l}\text { Inspiration for } \\
\text { choice of destination }\end{array}$} & \multicolumn{5}{|c|}{$\begin{array}{l}\text { Decision when hotel preference } \\
\text { is not available }\end{array}$} \\
\hline & (1) & (2) & (3) & (4) & $(5)$ \\
\hline Attract. at the dest. & 60 & 6 & 1 & 4 & 71 \\
\hline Accessibility & 11 & 2 & o & 1 & 14 \\
\hline Accommodation & 5 & 0 & 1 & 0 & 6 \\
\hline Others & 7 & o & 1 & o & 8 \\
\hline Total & 83 & 8 & 3 & 5 & 99 \\
\hline
\end{tabular}

Notes Column headings are as follows: (1) look for another accommodation within the destination, (2) postpone the trip till when I can book for the accommodation at the destination, (3) cancel the trip and search for another destination with the same hotel brand, (4) cancel the trip and look for another destination, (5) total.

Table 7 Chi-Square Tests

\begin{tabular}{lrrr}
\hline Item & $(1)$ & $(2)$ & $(3)$ \\
\hline Pearson Chi-Square & 9.839 & 9 & 0.364 \\
Likelihood ratio & 9.159 & 9 & 0.423 \\
Linear-by-linear association & 0.003 & 1 & 0.960 \\
No. of valid cases & 99 & & \\
\hline
\end{tabular}

Notes Column headings are as follows: (1) value, (2) degrees of freedom, (3) asymptotic significance (2-sided).

accessibility to and within the destination is their inspiration, while just $6.1 \%$ indicated the accommodation facility available at the destination. The remaining 8.1\% indicated some other factors, such as cost, familiar people at the destination and culture of the destination, as indicated in Table 5. 
Table 8 Spearman's Ranked Correlation Analysis of Elements of Destination Branding and Inspiration for Choice of Destination

\begin{tabular}{|c|c|c|c|c|c|c|c|c|}
\hline Element & $(1)$ & $(2)$ & (3) & (4) & (5) & (6) & (7) & $\overline{(8)}$ \\
\hline \multirow[t]{3}{*}{ (1) Key attractions } & (a) & 1.000 & 0.195 & $0.273^{\star *}$ & $0.301^{\star *}$ & $0.264^{\star *}$ & $0.306^{* *}$ & $0.368^{\star *}$ \\
\hline & (b) & - & 0.054 & 0.006 & 0.002 & 0.008 & 0.002 & 0.000 \\
\hline & (c) & 99 & 99 & 99 & 99 & 99 & 99 & 99 \\
\hline \multirow[t]{3}{*}{ (2) Accommodation facilities } & (a) & 0.195 & 1.000 & $0.572^{* *}$ & $0.679^{\star *}$ & 0.076 & $0.416^{\star *}$ & 0.056 \\
\hline & (b) & 0.054 & - & 0.000 & 0.000 & 0.455 & 0.000 & 0.585 \\
\hline & $(c)$ & 99 & 99 & 99 & 99 & 99 & 99 & 99 \\
\hline \multirow[t]{3}{*}{ (3) Infrastructure } & (a) & $0.273^{* *}$ & $0.572^{\star *}$ & 1.000 & $0.663^{* *}$ & $0.203^{*}$ & $0.478^{\star *}$ & 0.144 \\
\hline & (b) & 0.006 & 0.000 & - & 0.000 & 0.044 & 0.000 & 0.156 \\
\hline & (c) & 99 & 99 & 99 & 99 & 99 & 99 & 99 \\
\hline \multirow[t]{3}{*}{ (4) Services and facilities } & (a) & $0.301^{* *}$ & $0.679^{\star *}$ & $0.663^{\star *}$ & 1.000 & $0.225^{*}$ & $0.608^{\star *}$ & 0.152 \\
\hline & (b) & 0.002 & 0.000 & 0.000 & - & 0.025 & 0.000 & 0.132 \\
\hline & (c) & 99 & 99 & 99 & 99 & 99 & 99 & 99 \\
\hline \multirow[t]{3}{*}{ (5) Emotional appeal } & (a) & $0.264^{* *}$ & 0.076 & $0.203^{*}$ & $0.225^{*}$ & 1.000 & $0.315^{* *}$ & $0.400^{\star *}$ \\
\hline & (b) & 0.008 & 0.455 & 0.044 & 0.025 & - & 0.001 & 0.000 \\
\hline & $(c)$ & 99 & 99 & 99 & 99 & 99 & 99 & 99 \\
\hline \multirow[t]{3}{*}{ (6) Peace and Safety } & (a) & $0.306^{\star *}$ & $0.416^{\star *}$ & $0.478^{\star *}$ & $0.608^{\star *}$ & $0.315^{* *}$ & 1.000 & $0.250^{*}$ \\
\hline & (b) & 0.002 & 0.000 & 0.000 & 0.000 & 0.001 & - & 0.013 \\
\hline & (c) & 99 & 99 & 99 & 99 & 99 & 99 & 99 \\
\hline \multirow[t]{3}{*}{ (7) Scenic and Adventure } & (a) & $0.368^{* *}$ & 0.056 & 0.144 & 0.152 & $0.400^{* *}$ & $0.250^{*}$ & 1.000 \\
\hline & (b) & 0.000 & 0.585 & 0.156 & 0.132 & 0.000 & 0.013 & - \\
\hline & $(\mathrm{c})$ & 99 & 99 & 99 & 99 & 99 & 99 & 99 \\
\hline \multirow[t]{3}{*}{ (8) Inspiration for choice of destination } & (a) & $-0.227^{*}$ & 0.055 & -0.062 & 0.035 & 0.119 & -0.023 & -0.054 \\
\hline & (b) & 0.024 & 0.586 & 0.541 & 0.733 & 0.240 & 0.821 & 0.597 \\
\hline & (c) & 99 & 99 & 99 & 99 & 99 & 99 & 99 \\
\hline
\end{tabular}

Notes Row headings are as follows: (a) correlation coefficient, (b) significance (2-tailed), (c) N.

\section{Cross Tabulations and Correlation Analysis}

In continuation of the descriptive analysis, cross tabulation was used in analysis of both the decision the respondents will make when their preferred hotel is not available and the inspiration for their choice of hotel. Table 6 is a cross-tabulation of the two variables showing a summary of the relationship between them. From the table, it can be summarised that those who will look for other accommodation within the same destination are more interested in the attraction rather than the accommodation, and they constitute the majority in the cross tabulation.
To test the hypothesis, Spearman Rank Correlation analysis was used. The hypothesis for this research states that accommodation facilities in terms of its brand as a key element of destination have no effect on the inspiration for a choice of destination. According to the analysis of data presented in Table 8 , the relationship between accommodation facilities as an element of destination branding and the inspiration for a choice of destination is a weak relationship with $r=0.055$ and $p=0.586$; therefore, the null hypothesis is accepted, which means that there is no significant relationship between accommodation fa- 
Table 9 Correlation of Destination Brand and Hotel Brand

\begin{tabular}{llrr}
\hline Item & & $(1)$ & $(2)$ \\
\hline (1) Inspiration for choice & (a) & 1.000 & 0.020 \\
of destination & (b) & - & 0.843 \\
& (c) & 99 & 99 \\
\hline (2) Decision when hotel & (a) & 0.020 & 1.000 \\
preference is not available & (b) & 0.843 & - \\
& (c) & 99 & 99 \\
\hline
\end{tabular}

Notes Row headings are as follows: (a) correlation coefficient, (b) significance (2-tailed), (c) $N$.

cilities as a brand element for a destination and being an inspiration for the choice of destination to visit. Regarding other elements of destination branding and inspiration to travel, it is indicated in Table 6 that the emotional appeal of the destination to the tourists is more related to why people choose a destination with $r=0.119$ but it is not significant as $p=0.240$. From the analysis on the table, it can then be concluded that no individual element of destination branding can solely enhance the branding of a destination nor influence the decision of the choice of a destination, hence, all elements are important.

In a test of loyalty to hotel brand or destination brand, Spearman Rank Correlation analysis was used. The hypothesis states that there is no significant relationship between the loyalty to a hotel brand with the inspiration for the choice of a destination. The report of the analysis supports the research hypothesis that there is no statistically significant relationship between the two, as presented in Table 9 where $r=0.020$ and $p$ $=0.843$.

\section{Discussion}

As identified in the literature review, the marketing of a destination, also known as 'place marketing' is more complex than the marketing of other organisations, such as the hotels or transport service providers (Karavatsis \& Ashworth, 2005). Therefore, Echtner and Ritchie (2003) indicated that, for the successful promotion of the destination in the targeted markets, the destination must be differentiated from its competition. As a way of differentiating one destination from its competition, the availability of a branded hotel at the destination was assumed to be a differentiating factor (Dioko \& So, 2012), but from the finding, the availability of branded hotel does not influence their choice of destination. To some of the respondents, the availability of branded hotels in a destination indicates the quality of the destination, and it gives assurance of value, safety, quality service, assurance of comfortability, which makes it a significant part of the whole travel experience. Therefore, the availability of branded hotels can be seen as an added advantage in the promotion of the destination, which can also create an image of the destination as supported by Gilmore (2002), who sees destination branding as a re-positioning concept, and Curtis (2001), who sees destination branding as the reconstruction of the destination (Park \& Petric, 2006).

From the research findings, it was discovered that all the elements of destination branding are essential to the tourists and the enhancement of the brand of a destination (see Table 10) as supported by Cai (2002) who defined destination branding as a selection of a consistent element mix of a destination used to identify and distinguish the destination among other destinations. Therefore, according to Miličević, Mihalič, and Ivan (2016), in branding a destination, the managers of the destinations are expected to define their target group (i.e., to whom to communicate the destination brand). For some groups, the availability of branded hotels might not be a important element they seek in the brand of a destination, while to some it might be. It was noted that some people find the availability of branded hotels to be an assurance of the quality of the destination brand. Hence, the fact of a hotel brand as an element of destination branding cannot be totally neglected in the branding of a destination, according to Miličević et al. (2016).

Furthermore, in the test of loyalty to either the destination brand or hotel brand, it was discovered that the respondents are more loyal to the destination than the brand of hotel; this also indicates that the brand of the hotel cannot be considered to be a major branding element for a destination. According to Veríssimo et al. (2017), there are two dimensions to be considered in evaluating brand loyalty: emotional and rational di- 
Table 10 Elements of Destination Branding

\begin{tabular}{|c|c|c|c|c|c|c|c|}
\hline Elements & $(1)$ & (2) & (3) & $(4)$ & (5) & $(6)$ & (7) \\
\hline$N$ valid & 99 & 99 & 99 & 99 & 99 & 99 & 99 \\
\hline$N$ missing & $\mathrm{o}$ & $\mathrm{o}$ & $\mathrm{O}$ & $\mathrm{o}$ & $\mathrm{o}$ & $\mathrm{O}$ & $\mathrm{o}$ \\
\hline Mean & 4.38 & 3.72 & 3.55 & 3.83 & 4.14 & 4.26 & 4.16 \\
\hline Median & 5.00 & 4.00 & 4.00 & 4.00 & 4.00 & 5.00 & 4.00 \\
\hline Mode & 5 & 5 & 3 & 4 & 5 & 5 & 5 \\
\hline Standard deviation & 0.955 & 1.116 & 1.013 & 0.969 & 1.010 & 0.985 & 0.900 \\
\hline Variance & 0.912 & 1.246 & 1.026 & 0.940 & 1.021 & 0.971 & 0.810 \\
\hline Range & 4 & 4 & 4 & 4 & 4 & 4 & 4 \\
\hline Sum & 434 & 368 & 351 & 379 & 410 & 422 & 412 \\
\hline
\end{tabular}

Notes Column headings are as follows: (1) key attractions, (2) accommodation facilities, (3) infrastructure, (4) services and facilities, (5) emotional appeal, (6) peace and safety, (7) scenic and adventure.

mensions. These have been embedded in the questions on the decisions the respondents will make when their preferred brand of hotel is not available at the destination of interest, and also in the question on the inspiration of choice of destination to visit. Therefore, these variables are applicable as a test of loyalty to either the destination brand or hotel brand. The result of the finding can be said to be justified as this can be linked to brand equity as supported by Aaker (1996) who stated that loyalty is a core aspect of brand equity because it is able to reduce vulnerability of a destination to competitor's actions.

\section{Conclusion}

The study was carried out to identify the role of hotel brand on the branding of a destination, but the findings demonstrated that a branded hotel or accommodation facility available at the destination does not solely enhance the branding of a destination; rather, a combination of some elements does, as identified in Table 8. This, therefore, further supports the findings of Pike and Page (2014), who said the most comprehensive definition of destination branding has been that proposed by Blain, Levy, and Ritchie (2005), in collaboration with Berthon, Hulbert, and Pitt's (1999) model of the functions of a brand from the buyer and supplier's perspectives, which is given as: 'the set of marketing activities (1) that support the creation of a name, symbol, logo, word mark or other graphic that readily identifies and differentiates a destination; that (2) consistently convey the expectation of a memorable travel experience; (3) serve to consolidate and reinforce the emotional connection between the visitor and the destination; and (4) reduce consumer search costs and perceived risk.'

All of these activities collectively serve to create a destination image that positively influences consumer destination choice. In line with this, the research findings also show that tourists are more loyal to the destination brand than the hotel brand.

\section{References}

Aaker, D. A. (1991). Managing brand equity. New York, NY: The Free Press.

Aaker, D. A. (1996). Building strong brands. New York, NY: The Free Press.

Aaron, L. (2011). Mixed methods research. Radiology and Technology, 82(3), 274-275.

Alina, W. (2009). Designing brand identity: An essential guide for the entire branding team. Hoboken, NJ: Wiley.

Ashton, A. \& Scott, N. (2011). Hotel restaurant co-branding: The relationship of perceived brand fit with the intention to purchase. Journal of Vacation Marketing, 17(4), 275285.

Asuero, A. G., Sayago, A., \& González, A. G. (2006). The correlation coefficient: An overview. Critical Reviews in Analytical Chemistry, 36(1), 41-59.

Ashworth, G. (1993). Marketing places: What are we doing? In G. Ave, \& F. Corsico (Eds.), Urban marketing in Europe (pp. 643-649). Turin, Italy: Turina Incontra. 
Berger, B., \& Chiafor, Jr. (2007). Select-service hotels: A guide to understanding the lodging industry and one of its most attractive segments (Unpublished master thesis). Cambridge, m A: Massachusetts Institute of Technology.

Bhatia, A. K. (2006). The business of tourism: Concepts and strategies. New York, NY: Sterling.

Bhattacherjee, A. (2012). Social science research: Principles, methods, and practices. Tampa, FL: Open Textbook Library.

Berthon, P., Hulbert, J., \& Pitt, L. (1999). To serve or to create? Strategic orientations towards customers and innovation. California Management Review, 42(1), 37-58.

Binkowska, B. (2005). The New Zealand hotel industry: The role of image as a medium influencing company's competitiveness and customer loyalty towards brand (Unpublished masters thesis). Auckland, New Zealand: University of Technology.

Blackett, T. (2004). What is a brand. In R. Clifton \& J. Simmons (Eds.), Brands and Branding (pp. 13-26). London, England: Profile Books.

Blain, C. R. (2001). Destination branding in destination marketing organizations (Unpublished master thesis). University of Calgary, Calgary, Canada.

Blain, C., Levy, S. E., \& Ritchie, J. R. B. (2005). Destination branding: Insights and practices from destination management organizations. Journal of Travel Research, 43, 328-338.

Buhalis, D. (2000). Marketing the competitive destination for the future. Tourism Management, 21(1), 97-116.

Cai, L. (2002). Cooperative branding for rural destinations. Annals of Tourism Research, 29(3), 720-742.

Carbone, L. P., \& Haeckel, S. H. (1994). Engineering customer experiences. Marketing Management, 3(3), 9-19.

Chu, S., \& Keh, H. (2006). Brand value creation: Analysis of the Interbrand-Business Week brand value ranking. Marketing Letters, 17(1), 323-331.

Cobb-Walgren, C. J., Ruble, C. A., \& Donthu, N. (1995). Brand equity, brand preference, and purchase intent. Journal of Advertising, 24(Fall), 25-40.

Connell, J. (1992). Branding hotel portfolios. International Journal of Contemporary Hospitality Management, 4(1), 26-32.

Cooper, C. (2012). Essentials of tourism. Harlow, England: Pearson.

Creswell, J. W. (2003). Research design: Qualitative, quantitative, and mixed methods approaches (2nd ed.). Thousand Oaks, c A: Sage.

Curtis, J. (2001). Branding a state: The evolution of brand Oregon. Journal of Vacation Marketing, 7(1), 75-81.
Da Silveira, C., Lages, C., \& Simoes, C. (2013). Reconceptualizing brand identity in a dynamic environment. Journal of Business Research, 66(1), 28-36.

Dioko, L., \& So, S. (2012). Branding destinations versus branding hotels in a gaming destination: Examining the nature and significance of co-branding effects in the case study of Macao. International Journal of Hospitality Management, 31(2), 554-563.

Elbe, J., Hallen, L., \& Axelsson, B. (2009). The destinationmanagement organization and the integrative destination-marketing process. International Journal of Tourism Research, 11(3), 283-296.

Echtner, C., \& Ritchie, J. R. (2003). The meaning and measurement of the destination image. The Journal of Tourism Studies, 14(1), 37-48.

Forsgren, F., \& Franchetti, C. (2004). The marketing role of unique concepts for hotels in Sweden (Unpublished masters thesis). Göteborg, Sweden: Göteborg University.

Freund de Klumbis, D. (2002, April). Seeking the ultimate hotel experience. Peper presented at the 12th International Leisure and Tourism Symposium, Barcelona.

Fyall, A., \& Garrod, B. (2005). Tourism marketing: A collaborative approach. Clevedon, U K: Channel View Publications.

Fyall, A., \& Leask, A. (2006). Destination marketing: Future issues - strategic challenges. Tourism and Hospitality Research, $7(1), 50-63$.

Gartner, W. C. (1993). Image formation process. Journal of Travel and Tourism Marketing, 2(2-3), 191-215.

Gilmore, F. (2002). Branding for success. In N. Morgan, A. Pritchard, \& R. Pride (Eds.), Destination branding: Creating the unique destination proposition (pp. 57-65). Oxford, England: Butterworth Heinemann.

Hankinson, G. (2005). Destination brand images: A business tourism perspective. Journal of Service Marketing, 19(1), 24-32.

Helfert, G., Ritter, T., \& Walter, A. (2002). Redefining market orientation from a relationship perspective: Theoretical considerations and empirical results. European Journal of Marketing, 36, 1119-1139.

Iglesias, O. \& Bonet, E. (2012). Persuasive brand management: How managers can influence brand meaning when they are losing. Journal of Organizational Change Management, 25(2), 251-264.

Iglesias, O., Singh, J. J., \& Batista-Foguet, J. M. (2011). The role of brand experience and affective commitment in determining brand loyalty. Journal of Brand Management, 18(8), 570-582.

Ismail, A. R. (2011). Experience marketing: An empirical in- 
vestigation. Journal of Relationship Marketing, 10(3), 167201.

Jevons, C., Gabbott, M., \& De Chernatony, L. (2005). Customer and brand manager perceptions on brand relationships: A conceptual framework. The Journal of Product and Brand Management, 14(4/5), 300.

Johnson, G., \& Scholes, K. (2001). Exploring corporate strategy. Hemel Hempstead, England: Prentice Hall.

Kandampully, J., \& Suhartanto, D. (2000). Customer loyalty in the hotel industry: The role of customer satisfaction and image. International Journal of Contemporary Hospitality Management, 12(6), 346-351.

Karavatsis, M., \& Ashworth, G. (2005). City branding: An effective assertion of identity or a transitory marketing trick? Tijdschrift voor Economische en Social Geografie, 96(5), 506-514.

Kapferer, J. N. (2008). The new strategic brand management: Creating and sustaining brand equity long term. London, England: Kogan Page.

Keller, K. L. (1998). Strategic brand management: Building, measuring and managing brand equity. Upper Saddle River, NJ: Prentice Hall.

Keller, K., \& Lehmann, D. (2006). Brands and branding: Research findings and future priorities. Marketing Science, 25(6), 740-759.

Klaus, P., \& Maklan, S. (2007). The role of brands in a service-dominated world. Journal of Brand Management, 15(2), 115-122.

Kotler, P., \& Gertner, D. (2004). Country as a brand, product and beyond: A place marketing and brand management perspective. In N. Morgan, A. Pritchard, \& R. Pride (Eds.), Destination branding: Creating the unique destination proposition. Oxford, England: ButterworthHeinemann.

Leiper, N. (1995). Tourism management. Melbourne, Australia: RMIT Press.

MacDonald, S. \& Headlam, N. (N.d). Research methods handbook: Introductory guide to research methods for social research. Manchester, England: CLES.

Matthews, B., \& Ross, L. (2010). Research methods. London, England: Pearson Longman.

Medlik, S., \& Ingram, H. (200o). The business of hotels. Oxford, England: Butterworth-Heinemann.

Miličević, K., Mihalič, T., \& Ivan, S. (2016). An investigation of the relationship between destination branding and destination competitiveness. Journal of Travel \& Tourism Marketing, 34(2), 209-221.

Morgan, N. J., Pritchard, A., \& Piggott, R. (2003). Destination branding and the role of the stakeholders: The case of New Zealand. Journal of Vacation Marketing, 9(3), 285-299.

Morgan, N., Pritchard, A., \& Pride, R. (2004). Destination branding: Creating the unique destination proposition. Oxford, England: Butterworth Heinemann.

Nailon, P. (1982). Theory in hospitality management. International Journal of Hospitality Management, 1(3), 135143.

Olsen, M. D., Chung, Y., Graf, N., Lee, K., \& Madanoglu, M. (2004). Branding: Myth and reality in the hotel industry. Journal of Retail and Leisure Property, 4(2), 146-162.

O'Neill, J., \& Xiao, Q. (2006). The role of brand affiliation in hotel market value. Cornell Hospitality Quarterly, 47(3), 210-223.

Park, S., \& Petric, J. (2006). Destinations' perspectives of branding. Annals of Tourism Research, 33(1), 262-265.

Periera, R., Correia, A., \& Schutz, R. (2012). Destination branding: A critical overview. Journal of Quality Assurance in Hospitality and Tourism, 13(2), 81-102.

Pike, S. (2004). Destination marketing organisations. Oxford, England: Elsevier.

Pike, S. (2005). Tourism destination branding complexity. The Journal of Product and Brand Management, 14(4/5), 258.

Pike, S. (2008). Destination marketing: An integrated marketing communication approach. Amsterdam, The Netherlands: Butterworth-Heinemann.

Pike, S., \& Page, S. (2014). Destination marketing organizations and destination marketing: A narrative analysis of the literature. Tourism Management, 41, 202-227.

Pritchard, A., \& Morgan, N. J. (2001). Culture, identity, and tourism representation: Marketing Cymru or Wales? Tourism Management, 22(2), 167-179.

Qu, H., Kim, L. H., \& Im, H. H. (2011). A model of destination branding: Integrating the concepts of the branding. Tourism Management, 32(3), 465-476.

Randall, G. (2000). Branding: A practical guide to planning your strategy. London, England: Kogan Page.

Shoemaker, S., \& Shaw, M. (2008). Marketing essentials in hospitality and tourism: Foundations and practices. Upper Saddle River, NJ: Pearson Prentice Hall.

Simon, C. J., \& Sullivan, M. W. (1993). The measurement and determinants of brand equity: A financial approach. Marketing Science, 12(Winter), 28-52.

Stamboulis, Y., \& Skayannis, P. (2003). Innovation strategies and technology for experience-based tourism. Tourism Management, 24(1), 34-43.

Veal, A. (2011). Research methods for leisure and tourism: A practical guide. Harlow, England: Pearson. 
Veríssimo, J. M. C., Tiago, M. T. B., Tiago, F. G., \& Jardim, J. S. (2017). Tourism destination brand dimensions: An exploratory approach. Tourism and Management Studies, 14(4), 1-8.

Wahab, S., \& Cooper, C. (2001). Tourism, globalisation and the competitive advantage of nations. In S. Wahab, \& C. Cooper (Eds.), Tourism in the age of globalisation (pp. 321). London, England: Rouledge.
Zeithaml, V. A., \& Bitner, M. J. (1996). Services marketing. New York, NY: McGraw-Hill.

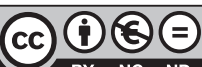

This paper is published under the terms of the Attribution- NonCommercial-NoDerivatives 4.0 International (CC B Y-NC-ND 4.0) License. 